\title{
Pelatihan Kurikulum 2013 Terhadap Guru Paud
}

\author{
Suri Handayani Damanik ${ }^{1 *}$, Gita Noveri Eza ${ }^{2}$, Roni Sinaga ${ }^{3}$, Rizky Ramadhani ${ }^{4}$, \\ Artha Mahindra Diputra ${ }^{5}$ \\ 1,2,3,4,5 Dosen PG PAUD Fakultas Ilmu Pendidikan Universitas Negeri Medan \\ Email: suridamanik@unimed.ac.id
}

\begin{abstract}
Abstrak. Kegiatan pengabdian ini bertujuan untuk membantu guru-guru sekolah mitra, yaitu TK Salsa dan TK Indah Mandiri, di Desa Cinta Rakyat Kecamatan Percut Sei Tuan Kabupaten Deli Serdang, dalam memahami kurikulum 2013, sehingga guru dapat membuat rencana pembelajaran, proses pembelajaran, dan penilaian pembelajaran sesuai dengan kurikulum 2013 yang telah dicanangkan oleh pemerintah. Materi yang disampaikan dalam kegiatan pelatihan kurikulum 2013 ini yaitu karakteristik, tujuan, landasan pengembangan kurikulum 2013 pendidikan anak usia dini, standar tingkat pencapaian perkembangan anak (STPPA), cakupan kriteria minimal setiap perkembangan pada STPPA (nilai agama dan moral, fisik motorik, kognitif, bahasa, sosial-emosional, dan seni), rumusan tentang kompetensi inti dan kompetensi dasar PAUD, serta keterkaitan STPPA, KD, KI, dan Indikator untuk pendidikan anak usia dini. Metode pelaksanaan kegiatan pengabdian dilakukan secara klasikal. Hasil kegiatan pengabdian kepada masyarakat ini adalah peningkatan pemahaman dan wawasan guru berkaitan dengan pelaksanaan kurikulum 2013 di sekolah mitra.
\end{abstract}

Kata kunci : pelatihan, kurikulum 2013, guru PAUD

\section{PENDAHULUAN}

Guru adalah unsur manusiawi dalam pendidikan. Guru adalah figur manusia sebagai sumber yang menempati posisi dan memegang peranan penting dalam pendidikan. Penelitian menunjukkan bahwa lebih dari tiga puluh persen keberhasilan pendidikan yang ditunjukkan oleh indikator prestasi belajar siswa ditentukan oleh guru (Supriadi, 1998). Ketika banyak orang mempersoalkan masalah kualitas pendidikan, tidak dapat dielakkan bahwa figur guru menjadi unsur yang dibicarakan, terutama yang menyangkut persoalan pendidikan formal di sekolah. Hal ini memang wajar, sebab guru merupakan ujung tombak yang berhubungan langsung dengan siswa sebagai subjek dan objek belajar. Bagaimanapun baik dan idealnya kurikulum pendidikan, tanpa diimbangi dengan kemampuan guru dalam mengimplementasikannya, maka semuanya akan kurang bermakna. Oleh sebab itu, untuk mencapai standar proses pendidikan, sebaiknya dimulai dengan menganalisis komponen guru. 
Secara hukum, negara telah mengakui bahwa guru merupakan suatu profesi yang memiliki kriteria-kriteria tertentu. Hal tersebut dinyatakan dengan jelas dan tegas pada Undang-Undang (UU) Nomor 20 Tahun 2003 tentang Sistem Pendidikan Nasional dan UU Nomor 14 Tahun 2005 tentang Guru dan Dosen, yang mewajibkan setiap pengembannya harus memenuhi kriteria dan atau persyaratan tertentu, diantaranya adalah (1) memiliki kualifikasi akademik, (2) memiliki kompetensi, (3) memiliki sertifikat pendidik, (4) sehat jasmani dan rohani, (5) memiliki kemampuan untuk mewujudkan tujuan pendidikan nasional.

Kekhususan profesi guru dari profesi lainnya adalah guru harus memiliki kompetensi keguruan, yaitu kompetensi pedagogik, kompetensi profesional, kompetensi sosial, dan kompetensi personal. Usman (2000) menyatakan bahwa kompetensi berarti suatu hal yang menggambarkan kualifikasi atau kemampuan seseorang, baik yang kualitatif maupun yang kuantitatif.

Idealnya seluruh kompetensi keguruan tersebut harus dimiliki oleh seluruh guru, mulai dari jenjang PAUD sampai guru pada jenjang Sekolah Menengah Atas, bahkan juga dosen di Perguruan Tinggi. Namun, hasil observasi dan wawancara kami dengan Kepala Sekolah dan Guru PAUD di Desa Cinta Rakyat, Kabupaten Deli Serdang, Provinsi Sumatera Utara, diperoleh informasi bahwa beberapa guru PAUD masih belum baik dalam salah satu aspek kompetensi pedagogik, yaitu kemampuan dalam mengembangkan kurikulum 2013, khususnya guru-guru di TK Salsa dan TK Indah Mandiri, Desa Cinta Rakyat, Kabupaten Deli Serdang, Provinsi Sumatera Utara. Guru-guru tersebut mengeluhkan bahwa mereka sudah menerapkan kurikulum 2013 tetapi masih belum maksimal, karena belum paham tentang penetapan kompetensi inti, kompetensi dasar, sampai indikator pembelajaran. Guru-guru pun belum paham tentang metode scientific yang menjadi ciri khas pembelajaran sesuai kurikulum 2013, sehingga pembelajaran yang dilakukan tidak ada bedanya dengan pembelajaran pada kurikulum sebelumnya. Metode penilaian dalam kurikulum 2013 pun belum dilakukan dengan baik oleh guru-guru, karena ketidakpahaman mereka. Jika kondisi ini dibiarkan, maka penerapan kurikulum 2013 tidak akan membawa 
dampak baik seperti yang diharapkan oleh pemerintah, khususnya di TK Salsa dan TK Indah Mandiri.

Kedua TK yang akan menjadi sasaran sekolah binaan dalam program pengabdian pada masyarakat ini berlokasi di Desa Cinta Rakyat, Kecamatan Percut Sei Tuan, Kabupaten Deli Serdang, Provinsi Sumatera Utara. TK Salsa berlokasi di Jalan Siliwangi no.1, Desa Cinta Rakyat. Jumlah guru di TK ini adalah sepuluh orang, dan hanya 2 orang yang sudah sertifikasi. TK Indah Mandiri berlokasi di Jalan KUD Dusun X, Desa Cinta Rakyat. Kepala Sekolah TK Indah Mandiri, yaitu Ibu Sepindah Nasari, S.Pd. (26 Tahun). Jumlah guru di TK Indah Mandiri sebanyak 5 orang (termasuk satu operator sekolah) dengan jumlah siswa sebanyak 38 orang. Dari lima guru yang mengajar di TK Indah Mandiri, baru satu orang guru yang telah tersertifikasi.

\section{METODE PELAKSANAAN}

Kegiatan ini dilakukan dalam bentuk pelatihan dengan melibatkan mitra sasaran yaitu TK Salsa dan TK Indah Mandiri, di Desa Cinta Rakyat, Kecamatan Percut Sei Tuan, Kabupaten Deli Serdang, Sumatera Utara yang meliputi tahap persiapan dan perencanaan, pelaksanaan, dan refleksi. Kegiatan ini dilaksanakan selama satu hari pada tanggal 23 September 2017.

Pelaksanaan dilakukan dengan menggunakan metode One day training, pelatihan diberikan kepada para guru TK Salsa dan TK Indah Mandiri, mensosialisasikan karakteristik, tujuan, landasan pengembangan kurikulum 2013 pendidikan anak usia dini, standar tingkat pencapaian perkembangan anak (STPPA), cakupan kriteria minimal setiap perkembangan pada STPPA (nilai agama dan moral, fisik motorik, kognitif, bahasa, sosial-emosional, dan seni), rumusan tentang kompetensi inti dan kompetensi dasar PAUD, serta keterkaitan STPPA, KD, KI, dan Indikator untuk pendidikan anak usia dini.

\section{HASIL DAN PEMBAHASAN}

Kegiatan pengabdian ini diawali dari tahap penjajakan/pra survey melalui metode bercakap-cakap untuk menemukan kendala yang dialami oleh guru-guru PAUD di Desa Cinta Rakyat selama proses belajar mengajar. Pada tahap ini, tim pelaksana 
dengan sekolah mitra, yaitu TK Salsa dan TK Indah Mandiri, membuat suatu kesepakatan bersama, yaitu melaksanakan pelatihan kurikulum 2013 terhadap guru TK Salsa dan TK Indah Mandiri, pada hari Sabtu, tanggal 23 September 2017 di salah satu ruang kelas TK Salsa, Desa Cinta Rakyat, Kecamatan Percut Sei Tuan, Kabupaten Deli Serdang Sumatera Utara.

Setiap sekolah mitra mengirimkan seluruh gurunya untuk mengikuti kegiatan pelatihan ini, sehingga total guru yang hadir dalam kegiatan pelatihan ini sejumlah 15 orang guru dari dua sekolah mitra.

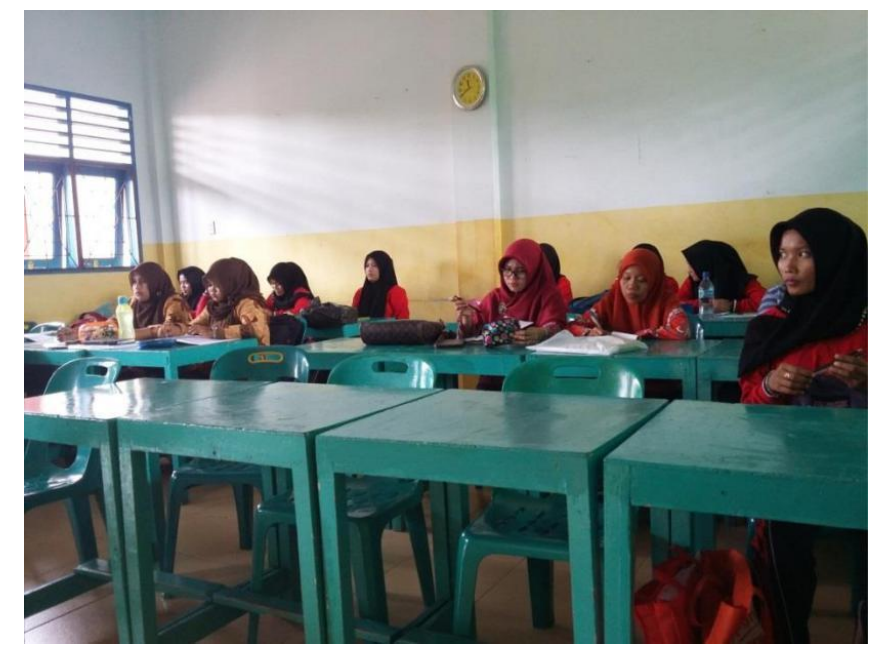

Gambar 1. Beberapa guru telah hadir menantikan dimulainya kegiatan

pelatihan kurikulum 2013 terhadap guru PAUD

Pelaksanaan kegiatan pengabdian masyarakat dilakukan dalam bentuk one day training (pelatihan 1 hari penuh). Pelatihan diberikan kepada para guru TK Salsa dan TK Indah Mandiri dengan mensosialisasikan karakteristik, tujuan, landasan pengembangan kurikulum 2013 pendidikan anak usia dini, standar tingkat pencapaian perkembangan anak (STPPA), cakupan kriteria minimal setiap perkembangan pada STPPA (nilai agama dan moral, fisik motorik, kognitif, bahasa, sosial-emosional, dan seni), rumusan tentang kompetensi inti dan kompetensi dasar PAUD, serta keterkaitan STPPA, KD, KI, dan Indikator untuk pendidikan anak usia dini. 
Bapak Dr. Aman Simaremare, MS menyampaikan materi yang berkaitan dengan karakteristik, tujuan, landasan pengembangan kurikulum 2013 pendidikan anak usia dini, dan standar tingkat pencapaian perkembangan anak (STPPA). Dari materi yang disampaikan ini diharapkan guru-guru memahami dan mampu melaksanakan kurikulum 2013 pendidikan anak usia dini dengan baik, sehingga dapat mendorong perkembangan peserta didik untuk mempunyai kesiapan menempuh jenjang pendidikan selanjutnya baik dalam hal sikap, spiritual, sikap sosial, pengetahuan, dan keterampilan.

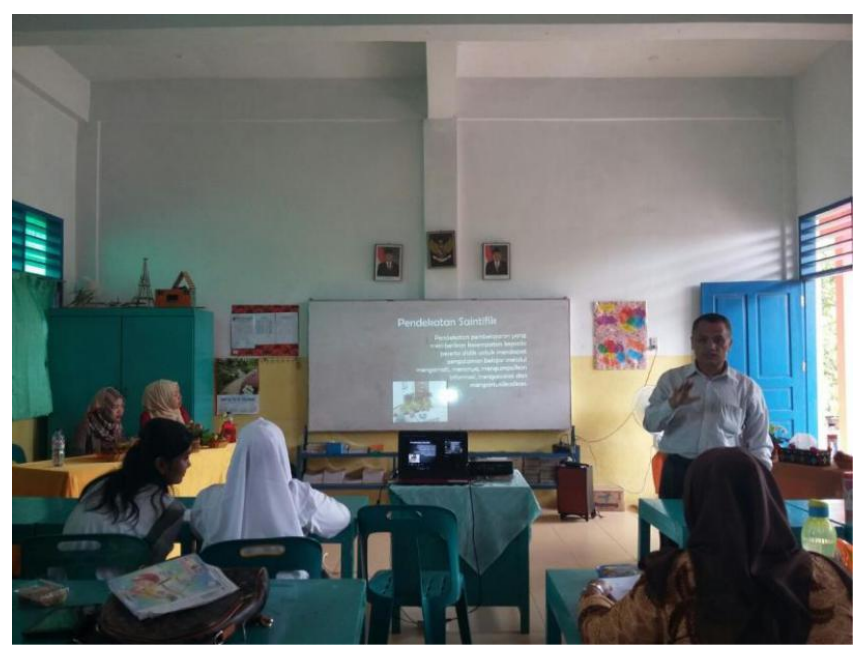

Gambar 2. Bapak Dr. Aman Simaremare, MS., sebagai ketua tim

pengabdian masyarakat sedang menyampaikan materi 1

Penyampaian materi dilanjutkan oleh Ibu Suri Handayani, S.Psi., M,Psi. Materi yang disampaikan adalah cakupan kriteria minimal setiap perkembangan pada standar tingkat pencapaian perkembangan anak (STPPA) yang mencakup aspek nilai agama dan moral, fisik motorik, kognitif, bahasa, sosial-emosional dan seni. Guru diharapkan dapat memahami bahwa kurikulum 2013 memiliki STPPA yang merupakan output dari layanan PAUD, sehingga dalam proses pembelajarannya 
STPPA ini agar selalu dikembangkan melalui pendekatan saintifik sesuai kurikulum 2013.

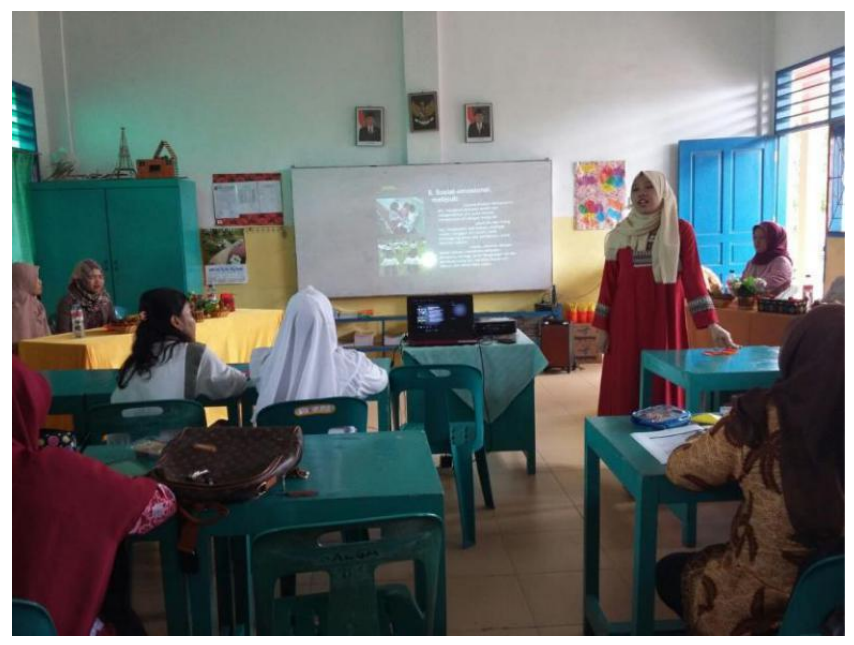

Gambar 5.3. Ibu Suri Handayani, S.Psi., M.Psi., sebagai anggota tim

pengabdian masyarakat sedang menyampaikan materi 2

Salah satu aspek dalam standar tingkat pencapaian perkembangan anak (STPPA) dalam kurikulum 2013 adalah aspek fisik motorik. Aspek ini meliputi motorik kasar (memiliki kemampuan kemampuan gerakan tubuh secara terkoordinasi, lentur, seimbang, dan lincah serta mengikuti aturan), motorik halus (memiliki kemampuan menggunakan alat untuk mengeksplorasi dan mengekspresikan diri dalam berbagai bentuk), dan kesehatan serta perilaku keselamatan (memiliki berat badan, tinggi badan, lingkar kepala sesuai usia serta memiliki kemampuan untuk berperilaku hidup bersih, sehat, dan peduli terhadap keselamatannya). Guru diharapkan mampu menyajikan pembelajaran yang dapat membantu anak memiliki kemampuan motoik kasar, motorik halus, dan kesehatan serta perilaku hidup sehat. Untuk motorik kasar dan motorik halus, guru-guru peserta pelatihan ini diminta untuk melakukan simulasi pengembangan motorik kasar dan motorik halus. 


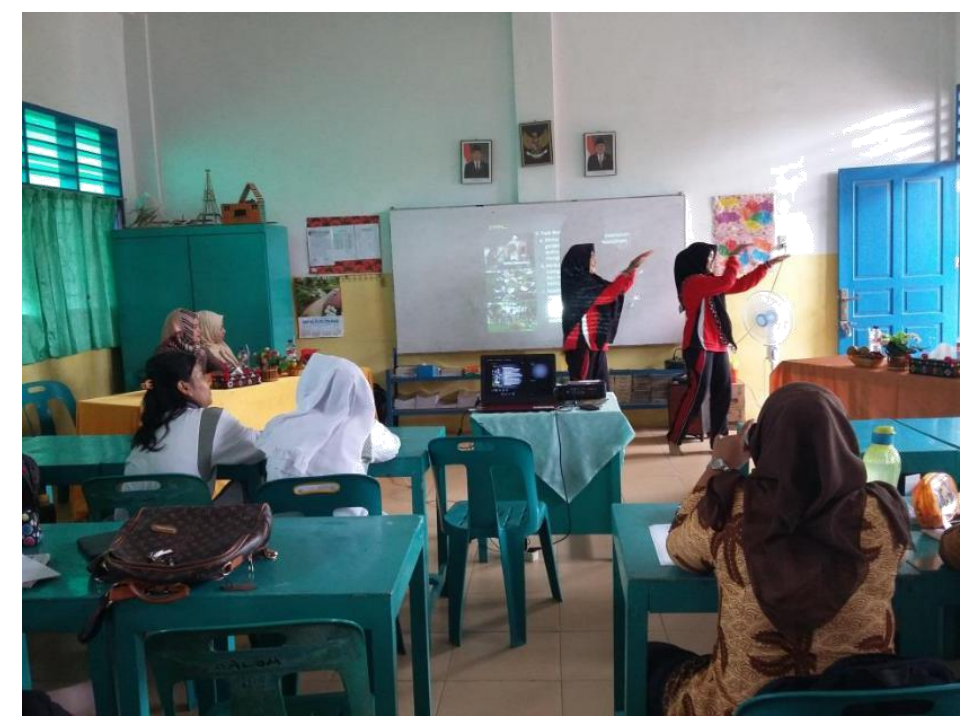

Gambar 4. Guru peserta kegiatan sedang melakukan

simulasi pengembangan motorik kasar

Materi selanjutnya tentang rumusan kompetensi inti dan kompetensi dasar PAUD, serta keterkaitan STPPA, KD, KI, dan Indikator untuk pendidikan anak usia dini yang disampaikan oleh Ibu Gita Noveri Eza, S.Pd., M.Pd.

\section{KESIMPULAN}

Kegiatan pengabdian masyarkat dengan judul Pelatihan Kurikulum 2013 Terhadap Guru PAUD Di TK Salsa dan TK Indah Mandiri Desa Cinta Rakyat Kecamatan Percut Sei Tuan Kabupaten Deli Serdang Sumatera Utara, telah dilaksanakan pada hari Sabtu tanggal 23 September 2017. Peserta kegiatan adalah guru-guru dari sekolah mitra, yaitu TK Salsa dan TK Indah Mandiri. Kegiatan dilakukan dalam bentuk oneday training (pelatihan satu hari penuh) berkaitan dengan kurikulum 2013 pendidikan anak usia dini, dengan narasumbernya adalah setiap anggota tim pelaksana. Selama kegiatan berlangsung, peserta mendapatkan banyak manfaat antara lain, bertambahnya pengetahuan mengenai karakteristik, tujuan, landasan 
pengembangan kurikulum 2013 pendidikan anak usia dini, standar tingkat pencapaian perkembangan anak (STPPA), cakupan kriteria minimal setiap perkembangan pada STPPA (nilai agama dan moral, fisik motorik, kognitif, bahasa, sosial-emosional, dan seni), rumusan tentang kompetensi inti dan kompetensi dasar PAUD, serta keterkaitan STPPA, KD, KI, dan Indikator untuk pendidikan anak usia dini. Diharapkan dengan bertambahnya pengetahun ini berdampak kepada peningkatan kompetensi pedagogik guru-guru di sekolah mitra.

Penulis juga mengemukakan saran-saran, yaitu kegiatan pelatihan untuk meningkatkan kompetensi guru PAUD ini perlu digiatkan untuk meningkatkan kualitas pendidikan anak usia dini menuju Indonesia lebih baik. Selain pelatihan kompetensi guru PAUD, pelatihan managemen PAUD dan pelatihan untuk orang tua siswa (parenting) bisa menjadi program kegiatan pengabdian masyarakat selanjutnya.

\section{DAFTAR PUSTAKA}

Usman (2000). Menjadi Guru Profesional. Bandung: Remaja Rosda Karya.

Wau, Yasaratodo. (2016). Profesi Pendidikan. Diktat Perkuliahan Universitas Negeri Medan. 